\title{
1. Introduction to the Handbook of Research on Management and Organizational History: the hotly contested present state of management and organizational history \\ Kyle Bruce
}

If ever there was an apposite time to write about management and organizational history ( $\mathrm{MOH}$ hereafter) this is certainly it, rendering the contents of this handbook all the more topical. As I was preparing the volume for submission, two very pointed reviews of $A$ New History of Management (NHM hereafter) (Cummings et al., 2017) appeared in the Journal of Management History (JMH hereafter) (Batiz-Lazo, 2019; Muldoon, 2019) of which, in the interests of full disclosure, I am an associate editor. In the interim, the editor-in-chief of JMH also published Work, Wealth, and Postmodernism: The Intellectual Conflict at the Heart of Business Endeavour (WWP hereafter) (Bowden, 2018), ostensibly as a retort to NHM. Throw in some unsavoury social media exchanges about aforesaid $J M H$ reviews, as well as a special issue devoted to history and organization studies in the world's leading management journal (Godfrey et al., 2016) and an earlier paper on a similar topic in the same journal (Rowlinson et al., 2014), and we have all the makings of an introduction for this handbook.

It would not be at all inaccurate or unfair to argue that this current ferment in $\mathrm{MOH}$ is the inevitable consequence of Clark and Rowlinson's (2004) provocative piece a decade and a half ago heralding a 'historic turn' in organization studies and advocating a more postmodernist approach to accounts as well as methods of dealing with the past. Similar provocations are discernible, I believe, in the founding of the journal Management and Organizational History in 2006. Among other "prospects" for the journal, the founding editors-in-chief cite the "historic turn in organization theory" and "the relevance for management and organization theory of philosophers of history such as Michel Foucault and Hayden White" (Booth and Rowlinson, 2006, p. 5). I also (autoethnographically?) witnessed this ongoing agitation at an Academy of Management professional development workshop I co-organized in 2014, as well as at a meeting of the Management History Research Group in 2015, where extraordinarily heated debate ensued concerning, respectively, "more critical, cultural, and qualitative historical research" and "method, methodology, and the historic-turn".

So, what's all the fuss about? In essence, NHM is a "counter-historical approach" encouraging management and organizational historians to follow Foucault's lead and eschew accounting for history "against a criterion of linear progress" which legitimizes the status quo and forecloses alternatives. Rather, we should seek to understand 
history by defining conditions in which people problematize what they are, what they do, and the world in which they live in certain epochs (Cummings et al., 2017, p. 36). In this sense, then, the pivotal question for $\mathrm{MOH}$ should be: why does management become a major problem in the early twentieth century? Cummings et al. counsel that we should doubt the conventional view that the answer to this question can be found in gradual evolution in response to changed socio-economic conditions but, rather, interrogate the problems influencing the framing of thinking at this moment in time. Following Foucault, these frames and problems determined and shaped the objects seen; object (management) and subject (management studies) as co-determining one another in response to the major problems of the day. The role of counter-history, therefore, is to raise doubts and alternatives to conventional truths about $\mathrm{MOH}$ in order to open things up and encourage thinking differently. They seek to question our assumptions of how management studies came into being, what it responded to, what 'good' it seeks to serve, what it is fundamentally about, and what it could be (Cummings et al., 2017).

For the author of $W W P, N H M$ and other "postmodernist calls for a 'historic turn' in organisational studies" are nothing short of a "puzzling and disingenuous ... assault on rationality" (Bowden, 2018, pp. 19, 23). In his editorial introduction to Batiz-Lazo's (2019) and Muldoon's (2019) stinging critiques of NHM, Bowden (2019, pp. 5, 6) declares these "highly significant intellectual challenges ... share commonalities with the repudiation of the so-called 'Historic Turn' 'scholarship", the latter which he regards as "intellectually shallow". Batiz-Lazo (2019, p. 122) goes on to assert that $N H M$ "is poised to do more harm than good - very much along the lines of tabloid charlatanerie linking vaccination to autism" and that it is "about time we stop further disruption and misinformation by addressing with robust arguments and firm empirical evidence the misconceptions, hyperbole, fallacies and general charlatanerie of the 'Historic Turn'". Muldoon (2019, pp. 127, 133), only mildly less scathing, observes that "the book falls flat, often bereft of evidence, makes claims that cannot be supported and has a smug attitude" with the "the lack of empathy for divergent viewpoints and facts ... the notable failure of the book" and which "causes them to lack precision".

The crux of this debate, I feel, revolves around a belief held by some members of the $\mathrm{MOH}$ scholarly community that, on the one hand, we are insufficiently conscious of our method, historiography, and of our 'truth claims'. On the other hand, there are others (myself included) who regard the latter position as overly concerned with what Frank Ankersmit called “a 'horizontality' of research - where one looks at what others have written - in lieu of a 'verticality' of interest, where the primary focus of one's research efforts is the objective reality of the world" (Bowden, 2019, p. 5). There is a genuine concern, in other words, that more and more recent work in $\mathrm{MOH}$ has been more about how one should or might do history rather than actually doing historical work.

The position adopted in this volume - also my personal position - is that unlike those scholars who, while calling for a cultural or historical 'turn' in $\mathrm{MOH}$, adopt the 'anti-realist' position that all interpretations of the past are as much invented as found, 
that no history can be literally 'factual' or completely 'found' or absolutely 'true', and that all historical accounts are ultimately metaphorical, and thus, meta-historical (Ankersmit, 1997; Jenkins, 1995, 2003; Munslow, 2010; White, 1973, 1987), I do believe there is a reasonably objective reality that might be observed and recorded by historians using archives and other primary source materials. Here I am guided by the work of Mark Bevir (1999, 2000, 2011) who argues that "although historians cannot be certain of the truth or falsity of their view of a historical meaning, they can reach an objective understanding that they have good reason to take as more or less true ... through a process of criticising and comparing rival sets of theories against criteria of accuracy, comprehensiveness, consistency, progressiveness, fruitfulness, and openness" (Bevir, 1999, p. 311).

In brief, Bevir regards cultural phenomena studied in the "human sciences" such as management as inscrutable unless studied historically, and herein, when studying such phenomena historically we are actually studying ideas - "meanings, intentionality or beliefs" - and so, "ideas have to be explained historically" (Bevir, 2011 , p. 114). I also take from him his focus on the "use of relics from the past to devise narratives that relate various historical objectives to one another" and his belief that "historians can give purposive explanations of [these] objects by highlighting a change in stance someone takes towards a given content" (Bevir, 1999, pp. 309, 314). Resultant historical knowledge cannot be justified as "objective", he maintains, "by reference to the procedures we use to reach it" (Bevir, 1999, p. 28) or by "confirmation or refutation of propositions by appeals to independent facts", but rather, by "comparing rival accounts" in terms of the criteria alluded to above (Bevir, 2011, p. 108). This "tentative and local" reasoning - which he terms "procedural individualism' - is critical for explaining beliefs and change of beliefs, as well as the fundamental importance herein of contextual conditions.

On this note, for Bevir, "texts do not have intrinsic meanings", but rather, "hermeneutic meanings are always meanings for specific individuals or a group of people". Such meanings are "intentional states, specifically beliefs" and "historians use texts as evidence of people's beliefs" (Bevir, 2011, p. 109). To account for these beliefs, the actions taken as a consequence of them, or how and why they might change over time, Bevir proffers that we must situate them in "webs of belief of specific individuals" (Bevir, 1999, p. 233) and, in turn, "against the background of contingent traditions and dilemmas" (Bevir, 2011, p. 119). And so, any problems that emerge with theories subjectively held by individuals about 'being in the world' are, as noted above, "local" and specific to those individuals' webs of belief so that in order to explain new beliefs, historians have to grasp "the dilemmas held and confronted" by particular individuals in particular times and places (Bevir, 1999, p. 233; Megill, 2000). In other words, and as cogently stated by Hyrkkänen (2009, p. 260), "the historian cannot understand the situation the same way as that the historical actor understood it unless the historian is scrupulously acquainted with the situation that the historical actor was facing".

In sum, he is of the view that "no particular evidence or method is either necessary or sufficient to ensure that historians understand an utterance correctly" and 
that "the sensible historian will cover all kinds of evidence, including the biography of the author, other statements by the author, other relevant writings, and the socio-economic context in which the author wrote" (Bevir, 2011, pp. 114-15). As Megill (2000) has noted, the aforementioned insights accord well with tacitly understood procedures that clear-thinking historians already know, though they seldom articulate for the simple reason that they just do not need to. In this context, I believe that a great deal of postmodern historiographical work - and many of the attempts to import same into $\mathrm{MOH}$ - sails perilously close to attempting to distract attention - by cloaking their writing in purposefully obscurantist and long-winded language - from the regrettable fact that these writers are simply unwilling or unable to actually do history.

\section{AN OVERVIEW OF THE VOLUME}

Reflective of the aforementioned orientation, but also mindful of the lack of diversity in much MOH (Cummings et al., 2017), the volume is divided into three sections: Part I: Classic Foundations, Part II: Alternative Voices, and Part III: About History. With this division, I am trying to capture the above-mentioned tension between the doing of historical work (Parts I and II) and writing about how to do it (Part III), as well as the need to surface different and/or unconventional perspectives (Part II). Accordingly, Part I deals with fairly familiar territory grounded in the Anglo-American tradition though even then, the intention is to offer new and/or revisionist viewpoints on classic foundations.

In Chapter 2, Stephen Cummings and Todd Bridgman continue their recent and successful strategy of questioning received wisdoms apropos seminal contributions and contributors to $\mathrm{MOH}$. Their chapter centres on Adam Smith, often listed as a pioneer in $\mathrm{MOH}$ in management textbooks. However, his treatment is generally limited to a few sentences about a pin factory and how his 'classic economics treatise' promoted the division of labour, which then required a gradual continuity of increasing employee control by a growing class of professional managers. Looking again at Smith, they argue, reveals a very different view of the role he could have played in conceptualizing management. Smith's intellectual innovations were not the promotion of laissez-faire economics and the division of labour, but rather the view that slavery and other forms of repression were wrong: ethically, fundamentally, but also economically. Taking this as a foundation enables us to look again at the historical relationship between management and slavery and to see a break, or discontinuity, between them, rather than continuity of approach and a subsequent silence and denial of the relationship.

In Chapter 3, Hindy Schachter continues her tireless 30-year revisionist work on Frederick Taylor. She explores how management textbooks used in American universities have portrayed Taylor's scientific management at different points in the twentieth century to show major shifts in the way management theorists have interpreted scientific management during this period and to suggest some reasons 
behind the changes. She finds a radical shift in treatment between the first and second halves of the period. Earlier textbooks discussed Taylor's work in glowing terms; many volumes from the 1960s and 1970s are overwhelmingly negative. As Taylor's works themselves did not change, a solution to the shift in interpretation has to be sought in the varying intellectual assumptions and social needs of the textbook authors in each period. Questions include: Why did so many industrial management textbooks adopt a positive scientific management framework in the Progressive era? Why did these authors believe Taylor's emphasis on principles and experimentation provided an important foundation for their discipline? Why did later authors by and large elect not to continue a positive portrayal of Taylor's work? Why did they turn from emphasizing his commitment to a science of work to comparing his theories of worker motivation with those of 1930s Human Relations theorist Elton Mayo? What precipitated the shift? How has revisionist work since the late 1980s countered the negative portrayal of Taylor's influence and reaffirmed a picture of key scientific management proponents favouring industrial democracy?

In Chapter 4, Jeff Muldoon and Yaron Zoller provide a meta-analytic review of the Hawthorne studies, one of the most debated and controversial topics in MOH. Their review points to several different trends, divided into several categories: general historical literature, competitors (and complements), context, the 'Hawthorne effect', criticisms, and defences of the Hawthorne studies. They also provide information on the social and personal context of the studies by providing sources of biographical information in the hope that scholars may use their review to develop future research on the Hawthorne studies.

In Chapter 5, Ellen S. O'Connor demonstrates that the field of management is grounded in a political project to increase self-governing capacity, a project making business the quintessential laboratory for organized, collective, creative life. Her purpose is to establish that social responsibility is not a response to neoliberalism, environmentalism, or other twentieth-century movements but rather is the field's DNA and reason for existing. Her intention is to stimulate engagement with this view, which contradicts received ideas about the nature and purpose of business. In the chapter she studies three founders of management: Joseph Wharton (1826-1909), Mary Parker Follett (1868-1933), and Chester Barnard (1886-1961). They worked towards the goal of a society that could make itself. Wharton lobbied to build economic and cultural autonomy for the US; Follett led social movements to remake the city, Boston, with and for marginal groups; and Barnard had a long career at New Jersey Bell Telephone, where he rose steadily for 18 years to become chief executive, a position he held for 21 years. Three times in his career, he took leaves of absence to lead government organizations during national crises. Wharton, Follett, and Barnard also pioneered in building a science and profession of management. Wharton founded the nation's first continuously operating school of business. Follett explicated a central focus, the principle of functional unity. Barnard (1938) inspired foundational works in organization science (Simon, 1947; March and Simon, 1958). History has credited them with founding management, but it has shrunk their vision 
as the term took on narrower meanings. Ellen's chapter recovers the extent of their project and upholds it as a present-day ambition.

Chapter 6 is a collaborative work from historians formerly or currently at the University of Exeter: Mairi Maclean, Gareth Shaw, Alan Booth, Rachel Pistol, and Morgen Witzel. Their chapter on the Rowntree lectures and the British interwar management movement challenges the received wisdom concerning British firms as overly conservative, comprising a small core of progressive firms amongst conservatively run, family-dominated businesses and displaying little interest in new managerial approaches, unlike US firms of the period. They argue that there was a nucleus of progressive British firms engaged in management learning through organized peer-to-peer communication, facilitated by lectures and Management Research Groups (MRGs) initiated by Seebohm Rowntree; fostering communities of practice designed to share management knowledge and experience. They suggest that British managers displayed greater openness to innovation and a willingness to confront shared problems than is recognized. They offer a provisional reinterpretation of British management practice that repositions business education relative to extant historiography; thereby contributing to a better-informed understanding of the evolution of British management learning in the interwar years.

Part II of the volume shift the focus away from the familiar and towards more unconventional histories in order to recover alternative voices 'silenced' by the dominance of the Anglo-American tradition in $\mathrm{MOH}$ or else by tradition and taken-for-granted assumptions about what $\mathrm{MOH}$ should focus on. Leading the charge is Richard Marens in Chapter 7, with his chapter exploring the French absolutist and militaristic roots of US corporations and management. He argues that while it is generally acknowledged that the giant American corporation was, in part, a product of capitalist relations inherited from Britain, scholars too often overlook the crucial role of the American military in making continent-spanning firms possible. Because the American army was politically limited in size, yet still tasked with removing natives and defending settlers over a vast region, West Point-trained officers learned to overcome these limits by following the pioneering efforts of French absolutist regimes in improving weapons technology and infrastructural engineering. As a result, the American army raised the efficiency and quality of manufacturing in ways that would become the basis of civilian mass production. Simultaneously, the infrastructural improvements the army generated in fighting the Indian wars spurred the development of transportation and communication systems necessary for creating a continent-spanning market capable of supporting a population of giant firms.

In Chapter 8, Tianyuan Yu, Albert J. Mills, and Jean Helms Mills propose a radically different starting point for consideration of the epistemological character of MOH: a Zen-informed approach that is neither wholly Western nor Eastern in the twenty-first century but a way of rethinking knowledge that crosses geopolitical boundaries. They start by reconfiguring Burrell and Morgan's sociological framework, informed by the Zen spirit of non-duality and non-attachment. The proposed 'global model' provides an innovative solution to the problem of paradigm incommensurability. They also suggest that the symbolic representation of Zen in MOS is 
something 'global' in contrast to the bipolar, linear, two-dimensional matrices typical in Western theoretical constructions. Accordingly, a Zen approach is a hybrid version or a multi-paradigm approach. They use a cross-cultural study of a social phenomenon - the divergent discourses on the Weberian notion of bureaucracy in China and Canada - to explore the potential of a Zen-informed approach.

In Chapter 9, Alex Gillett and Kevin Tennent continue their work on project-based industries which they argue allows largely unexploited opportunities for empirical, methodological, and theoretical contributions to the field of MOH. McDowell (2015) and Scranton (2014) demonstrate that the study of projects can enable an understanding of temporary and virtual organizations that link together multiple agencies each contributing to an overall value or 'legacy' comprising outputs and outcomes. Gillett and Tennent propose that researching global or continental scale sport mega event projects can capture these attributes, for example, the delivery and associated long-term legacy of the Olympic Games or FIFA World Cup. Project management history therefore allows a window onto the delivery of a project as well as a broader opportunity to study the ways that organizations and individuals within them cooperate to deliver outcomes allowing management historians to contribute to debates around the usefulness of such events to society, as well as the institutional context within which they are nested.

In Chapter 10, Amon Barros and Sérgio Wanderley argue that knowledge about management and organizations is always localized in time and space. Inscribing time into place is also a way to write unique histories. They depart from these assertions to present a contextual frame that allows understanding of the relationship between Brazil and the promise of modernity. Brazilian elites tried to lead and control the country towards modernity under three different superposed waves. The first wave they name "To be modern is to be white". The second wave they depict as "To be modern is to be developed". Finally, they depict the third attempt towards modernity as "To be modern is to be open". The attempts of Brazilians to develop and modernize the country give a unique context in which management and organization theories are deployed and must be understood. Thus, they emphasize the importance of taking place into account when writing $\mathrm{MOH}$.

In Chapter 11, Nelarine Cornelius argues that colonization and empire, in various forms, are central to the story of Britain's relationship with Africa. Her interest lies also in the antecedence to these periods. She feels it important to explore how encounters between Britain and Africa developed, from the perspective of the role of the British crown and state (crown/state), and in particular, the role of commercial activities and crown/state sponsorship of the action of traders and venturers, specifically. What emerges from this part of her inquiry is the long association between the British Isles and Africa, with many of the earliest encounters revealing very different encounters and attitudes to those that prevailed later in British history.

Finally, in Part III, we turn to writing about history and discussions of how history might be done. Again, the intention was to surface novel or unconventional approaches to these fiercely contested issues and it is not entirely coincidental that all these chapters are from authors based in Canada and/or as having some affiliation 
with the remarkable Albert Mills. In Chapter 12, Kristin S. Williams offers a new conceptual model called feminist critical historiography. The approach fuses critical discourse analysis and antenarrative theme analysis to aid in the critical study of history from a feminist perspective. Williams outlines the approach in detail and concludes with a small case study which illustrates how the method can be employed. Feminist critical historiography demonstrates how a feminist poststructural lens and a collaborative methodology can capture the role of discourses and narratives (macro/ micro and institutional/personal) in concealing a more fragmented view of history. The approach openly contests taken for granted accounts and truth statements while also revealing what is hidden from view (and how) in management history, including the lost contributions of female leaders and the gendered and limited scope of the field of $\mathrm{MOH}$.

In Chapter 13, Bill Foster, Diego Coraiola, Chris Quinn-Trank, and François Bastien argue that there is an understanding that organizational identification is a process deeply embedded in the past. Yet, until recently, the historical mnemonic connection between people and organizations has been ignored. Organizational re-membering is the explicit connection between rhetorical history, organizational memory, and organizational identification. Nevertheless, we know little about how this process works. In this chapter, the authors propose a theoretical model that explicates and identifies the components of organizational re-membering. Furthermore, they discuss the different boundary conditions that they feel lead to the successful initiation of the process.

Finally, in Chapter 14 Gabie Durepos, Albert J. Mills, and Patricia McLaren ask who is the management historian? The question is timely because many $\mathrm{MOH}$ researchers now do history, but they are doing it without conventional history training. This begs the question: Are they licensed to write history and can they legitimately translate the past into history? In this chapter, they suggest de-privileging the historian as the sole arbiter of history to instead see her as an actor-network. Implying that the historian is an actor-network reminds us to consider the (human, non-human, and non-corporeal) actors in her surroundings that have helped shape her formative professional development. To the extent that the historian is an outcome of, and stands on behalf of, her historical context, asking who she is necessitates an engagement with the notion of context.

\section{REFERENCES}

Ankersmit, F. 1997. Historiography and postmodernism. In K. Jenkins (Ed.), The Postmodern History Reader. London: Routledge, 277-97.

Barnard, C. 1938. The Function of the Executive. Boston, MA: Harvard University Press.

Batiz-Lazo, B. 2019. What is new in "a new history of management"? Journal of Management History, 25(1), 114-24.

Bevir, M. 1999. The Logic of the History of Ideas. Cambridge: Cambridge University Press.

Bevir, M. 2000. The logic of the history of ideas: Rethinking history. The Journal of Theory and Practice, 4(3), 295-300. 
Bevir, M. 2011. The logic of the history of ideas: Then and now. Intellectual History Review, 21(1), 105-19.

Booth, C. and Rowlinson, M. 2006. Management and organizational history: Prospects. Management and Organizational History, 1(1), 5-30.

Bowden, B. 2018. Work, Wealth, and Postmodernism: The Intellectual Conflict at the Heart of Business Endeavour. New York: Palgrave Macmillan.

Bowden, B. 2019. Editorial. Journal of Management History, 25(1), 2-8.

Clark, P. and Rowlinson, M. 2004. The treatment of history in organization studies: Toward an 'historic turn'? Business History, 46(3), 331-52.

Cummings, S., Bridgman, T., Hassard, J., and Rowlinson, M. 2017. A New History of Management. Cambridge: Cambridge University Press.

Godfrey, P., Hassard, J., O'Connor, E., Rowlinson, M., and Ruef, M. 2016. What is organizational history? Toward a creative synthesis of history and organization studies. Academy of Management Review, 41(4), 590-608.

Hyrkkänen, M. 2009. All history is, more or less, intellectual history: R. G. Collingwood's contribution to the theory and methodology of intellectual history. Intellectual History Review, 19(2), 251-63.

Jenkins, K. 1995. On What is History? London: Routledge.

Jenkins, K. 2003. Rethinking History. London: Routledge.

March, J. and Simon, H. 1958. Organizations. New York: John Wiley.

McDowell, M.L. 2015. Towards a critical dialogue between the history of sport, management history, and sport management/organization studies in research and teaching. The International Journal of the History of Sport, 32(15), 1750-1758.

Megill, A. 2000. Imagining the history of ideas. Rethinking History, 4(3), 333-40.

Muldoon, J. 2019. Stubborn things: Evidence, postmodernism and the craft of history. Journal of Management History, 25(1), 125-36.

Munslow, A. 2010. The Future of History. New York: Palgrave Macmillan.

Rowlinson, M., Hassard, J., and Decker, S. 2014. Strategies for organizational history: A dialogue between historical theory and organization theory. Academy of Management Review, 39(3), 250-274.

Scranton, P. 2014. Projects as a focus for historical analysis: Surveying the landscape. History and Technology, 30(4), 354-73.

Simon, H. 1947. Administrative Behavior: A Study of Decision-Making Processes in Administrative Organization. New York: Macmillan.

White, H. 1973. Metahistory: The Historical Imagination in Nineteenth-Century Europe. Baltimore, MD: Johns Hopkins University Press.

White, H. 1987. The Tropics Discourse: Essays in Cultural Criticism. Baltimore, MD: Johns Hopkins University Press. 